\title{
MICRODETERMINATION OF SERUM CALCIUM USING THE EEL FLAME PHOTOMETER
}

\author{
BY \\ E. C. BUTTERWORTH \\ From the Pathology Department, the North Staffordshire Royal Infirmary, Stoke-on-Trent
}

(RECEIVED FOR PUBLICATION OCTOBER 20, 1956)

Flame photometry has many applications, and in the clinical field its use in the estimation of serum sodium and potassium is now well established. Difficulties have been encountered in the estimation of serum calcium by flame photometry, since the emission spectrum of calcium is relatively weak and is subject to interference by the presence of other ions, e.g., sodium. Although many methods have been published in America, using chiefly the Beckman DU spectrophotometer with flame attachment and an oxy-acetylene flame (Severinghaus and Ferrebee, 1950; Mosher, Itano, Boyle, Myers, and Iseri, 1951 ; Kingsley and Schaffert, 1953), only two procedures have been described using the Eel flame photometer (Powell, 1953 ; Llaurado, 1954) which is the most used British commercial instrument. Consequently in this country, at least, serum calcium is still widely estimated by the classical permanganate titration method. This method, which gives reproducible results in skilled hands, can lead to gross errors with faulty technique and is not suitable if much less than $2 \mathrm{ml}$. serum is available. Furthermore, the results obtained may not necessarily give the true amount of calcium present. Insufficient washing of the calcium oxalate precipitate leads to high results due to the presence of titratable ammonium oxalate, and too much washing produces low results on account of loss of calcium oxalate in the washing fluid. In flame-photometric methods similar problems are present. Excess oxalate depresses the emission of the calcium flame, sodium and potassium have a positive interference effect, and the possibility of loss of calcium in the washing fluid is still present. An attempt has been made to overcome these difficulties. Owing to the increasing demand for serum calcium estimations in infants, a micro-calcium method, simple to perform and sufficiently accurate and reliable for the routine estimation of serum calcium, is very desirable. The aim of the author has been to devise such a method using $0.2 \mathrm{ml}$. serum and the Eel flame photometer.

\section{Preliminary Experiments}

On a micro scale the direct determination of serum calcium, i.e., by simple dilution, requires primarily a sensitive flame photometer. The Eel instrument does not possess the required sensitivity, and it was therefore decided that calcium would have to be separated first as oxalate.

Llaurado (1954) has studied the effect of $\mathrm{Na}^{+}, \mathrm{K}^{+}$, and oxalate ions on the estimation of serum calcium by flame photometry after preliminary separation of calcium oxalate. He uses a "washing" technique which eliminates the effect of $\mathrm{Na}^{+}$and $\mathrm{K}^{+}$, but in order to remove the interference due to oxalate he heats the calcium oxalate precipitate at 300 to $400^{\circ} \mathrm{C}$. overnight in a furnace, destroying any ammonium oxalate remaining after precipitation and converting the calcium oxalate into calcium carbonate. As a standard, calcium carbonate in dilute hydrochloric acid is used so that both standard and unknown contain the same ions. The heating of the calcium oxalate precipitate delays the completion of the analysis and increases the possibility of loss of precipitate which can easily occur if the calcium oxalate is incompletely dried before being placed in the furnace. It was thought advisable to avoid this stage, if possible, and as a first step it was decided to use an acid solution of calcium oxalate as standard. This solution, made from calcium carbonate and oxalic acid, contains equimolecular proportions of calcium and oxalic acid in $0.5 \mathrm{~N} \mathrm{H}_{2} \mathrm{SO}_{4}$.

A further stage in the development of the micro method was to increase the sensitivity of the flame photometer. This can be done directly by increasing the working air pressure above the usual $10 \mathrm{lb}$./sq. in. or indirectly by increasing the emission of the sprayed solution. When the air pressure is increased a greater flow of gas is required, and some difficulty may be experienced in working the instrument at higher pressures if the gas supply is poor. Occasionally in this department the gas supply falls below the minimum requirements in the period immediately before lunch, but at all other times the instrument works satisfactorily at $15 \mathrm{lb}$./sq. in. air pressure. The lunch-time period is now avoided for spraying and no further difficulty has been experienced. The makers have given an assurance that the instrument can safely be worked at this higher pressure. If, however, for some 
reason, the gas pressure remains persistently too low to work at $15 \mathrm{lb}$./sq. in. air pressure satisfactory results can be obtained at $10 \mathrm{lb}$. pressure, although there is some loss in sensitivity and the galvanometer readings are reduced by about $25 \%$. Recovery experiments at $10 \mathrm{lb}$. pressure are given in Table IV. Except where stated, the results which follow were all obtained using an air pressure of $15 \mathrm{lb}$./sq. in.

Kingsley and Schaffert (1954) increase the sensitivity by the use of organic solvents. Their procedure is a direct method using acetone-glacial acetic acid-water mixture $(27: 9: 4)$, with the addition of $0.02 \%$ "sterox" (a non-ionic wetting agent) as the diluting fluid. An exhaustive search for suitable organic solvents has not been made, but experiments carried out using standard calcium oxalate in $0.5 \mathrm{~N} \mathrm{H}_{2} \mathrm{SO}_{4}$ diluted with aqueous solution of the aliphatic alcohols -methyl, ethyl, iso-propyl, and propyl-showed that the sensitivity increased according to the homologous series (Table I). After further investigation $10 \%$ $(\mathrm{v} / \mathrm{v})$ propyl alcohol was chosen as a suitable solution which would increase the sensitivity, yet at the same time give a steady galvanometer reading.

\section{TABLE I}

GALVANOMETER READINGS SHOWING EFFECT OF ALCOHOLIC SOLUTIONS AS DILUTING FLUIDS

\begin{tabular}{|c|c|c|c|c|c|}
\hline \multicolumn{2}{|c|}{$\begin{array}{c}\text { Alcoholic Solutions } \\
(\%)(v / v)\end{array}$} & 5 & 10 & 15 & 20 \\
\hline $\begin{array}{l}\text { Methyl alcohol } \\
\text { Ethyl } \\
\text { iso-Propyl, } \\
\text { Propyl ., }\end{array}$ & $\begin{array}{l}\cdots \\
\cdots \\
\cdots \\
\cdots\end{array}$ & $\begin{array}{l}15 \cdot 0 \\
16 \cdot 0 \\
17 \cdot 0 \\
17 \cdot 5\end{array}$ & $\begin{array}{l}15 \cdot 5 \\
17 \cdot 0 \\
19 \cdot 0 \\
19 \cdot 5\end{array}$ & $\begin{array}{l}16 \cdot 5 \\
19 \cdot 0 \\
21 \cdot 0 \\
21 \cdot 5\end{array}$ & $\begin{array}{l}18 \cdot 0 \\
20 \cdot 0 \\
22 \cdot 5 \\
23 \cdot 0\end{array}$ \\
\hline
\end{tabular}

Water reading $=13 \cdot 0$.

Calcium oxalate standard $(10 \mathrm{mg} . \%), 1 \mathrm{ml}$, in $0.5 \mathrm{~N} \mathrm{H}_{2} \mathrm{SO}_{4}$ diluted with $3 \mathrm{ml}$. alcoholic solution or $3 \mathrm{ml}$. water before spraying.

The next objective was to obtain the relationship between galvanometer readings and calcium concentrations in acid solutions of calcium oxalate, diluted with $10 \%$ propyl alcohol. With the flame and instrument set according to the directions given in the experimental section, it was found that a linear relationship exists over a range 5.0 to $20.0 \mathrm{mg}$. Ca \%. Typical

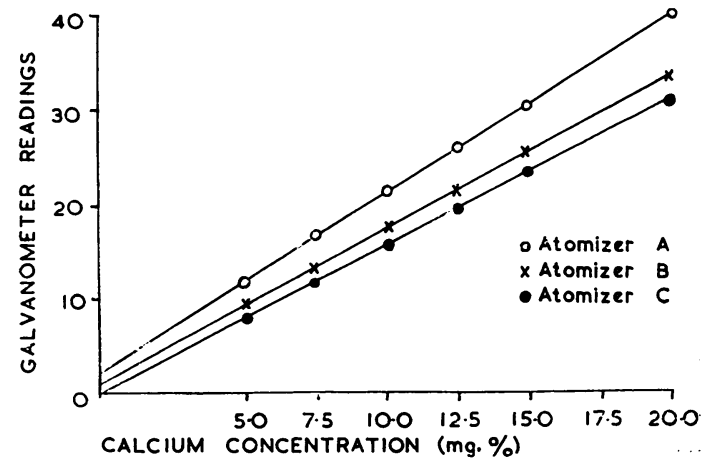

FIG. 1.-Relationship between galvanometer readings and calcium concentration when acid solutions of calcium oxalate $(1 \mathrm{ml}$.) diluted with $10 \% \mathrm{v} / \mathrm{v}$ propyl alcohol $(2 \mathrm{ml}$.) are sprayed in the Eel flame photometer. curves are given in Fig. 1. Readings vary slightly with different flame conditions and also quite markedly with different atomizers. The latter may be due to different cooling effects of the liquid when sprayed through atomizers of different bore. On account of this variability results for unknown solutions are obtained by interpolation with two standards in a similar manner to that used in the method of Llaurado (see experimental section).

Oxalate Interference.-The degree of interference of excess oxalate ions on standard calcium oxalate solutions was next determined. No interference was observed until a large excess of ammonium oxalate was present (Table II). It seems unlikely that sufficient ammonium oxalate will remain

TABLE II

EFFECT OF AMMONIUM OXALATE SOLUTION ON GALVANOMETER READINGS

\begin{tabular}{|c|c|c|c|}
\hline $\begin{array}{l}\text { Standard } \\
\text { Solution of } \\
\text { Calcium } \\
\text { Oxalate } \\
(\mathrm{mg} . \%)\end{array}$ & Water & $\begin{array}{c}\text { Saturated } \\
\text { Ammonium } \\
\text { Oxalate } \\
\text { Diluted } 1 \text { in } 5\end{array}$ & $\begin{array}{c}\text { Saturated } \\
\text { Ammonium } \\
\text { Oxalate }\end{array}$ \\
\hline $\begin{array}{r}5 \cdot 0 \\
10 \cdot 0 \\
15 \cdot 0 \\
20 \cdot 0\end{array}$ & $\begin{array}{l}10 \cdot 5 \\
20 \cdot 0 \\
29 \cdot 0 \\
38 \cdot 0\end{array}$ & $\begin{array}{l}11 \cdot 0 \\
200 \\
28 \cdot 5 \\
38 \cdot 0\end{array}$ & $\begin{array}{r}9 \cdot 5 \\
17 \cdot 5 \\
26 \cdot 0 \\
34 \cdot 5\end{array}$ \\
\hline
\end{tabular}

Calcium oxalate standard, $1 \mathrm{ml}$, in $0.5 \mathrm{~N} \mathrm{H}_{2} \mathrm{SO}_{4}$ diluted with $2 \mathrm{~m} / \mathrm{C}$ $10 \%$ propyl alcohol and $0.4 \mathrm{ml}$. water or ammonium oxalate solution

to interfere after serum calcium has been precipitated with saturated ammonium oxalate. If, however, serum calcium can be precipitated with a weaker solution of ammonium oxalate, which itself causes no interference, the problem of any interference from excess oxalate remaining after precipitation no longer exists. It has been established by comparing results with those obtained by the method of Llaurado that $0.4 \mathrm{ml}$. of a $1 / 5$ dilution of saturated ammonium oxalate is sufficient to precipitate the calcium in 0.2 $\mathrm{ml}$. serum in half an hour.

Sodium and Potassium Interference-Calcium oxalate is precipitated from $0.2 \mathrm{ml}$. serum by the addition of dilute ammonium oxalate solution. The precipitate is centrifuged, drained for $10 \mathrm{~min}$., and dissolved in $1 \mathrm{ml}$. $0.5 \mathrm{~N} \mathrm{H}_{2} \mathrm{SO}_{4}$, when $2 \mathrm{ml}$. $10 \%$ propyl alcohol is added and the $\mathrm{Na}^{+}$and $\mathrm{K}+$ concentrations of the solution found by flame photometry using a blank solution ( $1 \mathrm{ml} .0 .5 \mathrm{~N} \mathrm{H}_{2} \mathrm{SO}_{4}+2 \mathrm{ml} .10 \%$ propyl alcohol) for adjusting the galvanometer to zero. Results are given in Table III. A solution containing

TABLE III

AMOUNTS OF SODIUM AND POTASSIUM IN $\mathrm{H}_{2} \mathrm{SO}_{4}$-PROPYL ALCOHOL SOLUTIONS OF CALCIUM OXALATE PRECIPITATED FROM SERA

\begin{tabular}{c|c|c}
\hline Serum & Sodium (mg.\%) & Potassium (mg.\%) \\
\hline A & 0.33 & 0.026 \\
B & 0.46 & 0.026 \\
C & 0.38 & 0.031 \\
D & 0.38 & 0.021 \\
\hline
\end{tabular}


both $\mathrm{Na}^{+}$and $\mathrm{K}^{+}$, when added to standard calcium oxalate solutions $(5,10$, and $15 \mathrm{mg} . \%)$ to give final concentrations of $0.6 \% \mathrm{Na}$ and $0.06 \% \mathrm{~K}$, has no effect on the standard galvanometer readings. As the concentrations of $\mathrm{Na}$ and $\mathrm{K}$ found do not exceed these figures, it is unnecessary, using dilute ammonium oxalate for precipitation, to wash the calcium oxalate precipitate before dissolving it in acid.

Recovery of $\mathrm{Ca}^{+}+$Added to Serum.-Calcium is added to serum to cover a wide range. Results show satisfactory recovery both at $15 \mathrm{lb}$. and $10 \mathrm{lb}$./sq. in. air pressure, and are given in Table IV together with the results obtained by the method of Llaurado.

TABLE IV

COMPARATIVE RESULTS OF CALCIUM ADDED TO SERUM

\begin{tabular}{|c|c|c|c|c|}
\hline \multirow{3}{*}{$\begin{array}{l}\text { Calcium } \\
\text { Added } \\
(\mathrm{mg} . \%)\end{array}$} & \multicolumn{4}{|c|}{ Calcium Content (mg.\%) } \\
\hline & \multicolumn{2}{|c|}{ Serum A } & \multicolumn{2}{|c|}{ Serum B } \\
\hline & $\begin{array}{l}\text { Micro } \\
\text { Method }\end{array}$ & Llaurado & $\begin{array}{c}\text { Micro } \\
\text { Method* }\end{array}$ & Llaurado \\
\hline $\begin{array}{r}-2 \\
4 \\
6 \\
8 \\
10\end{array}$ & $\begin{array}{r}7 \cdot 5 \\
9.4 \\
11 \cdot 3 \\
13 \cdot 3 \\
15 \cdot 3 \\
17 \cdot 5\end{array}$ & $\begin{array}{r}7.4 \\
9.6 \\
11.4 \\
13.3 \\
15.5 \\
17.4\end{array}$ & $\begin{array}{r}6.9 \\
8.9 \\
10.7 \\
12.9 \\
14.7 \\
16.8\end{array}$ & $\begin{array}{r}6.8 \\
8.8 \\
10.9 \\
12.6 \\
14.6 \\
16.7\end{array}$ \\
\hline
\end{tabular}

* At $10 \mathrm{lb}$. $/ \mathrm{sq}$. in. air pressure.

Comparison of Flame Photometric and Permanganate Methods.-Results obtained with the flamephotometric method agree reasonably closely with those of the permanganate titration method of Clark and Collip (1925) and are given in Table V. There is good agreement between duplicate estimations by the micro method, the galvanometer readings differing at the most by $\frac{1}{4}$ division, which corresponds to a difference of $0.3 \mathrm{mg}$. $\% \mathrm{Ca}$ in the final result.

TABLE V

COMPARATIVE RESULTS FOR SERUM CALCIUM BY MICRO AND PERMANGANATE METHODS

\begin{tabular}{|c|c|c|c|}
\hline \multicolumn{3}{|c|}{ Micro Method (mg.\% Ca) } & \multirow{2}{*}{$\begin{array}{c}\text { Permanganate } \\
\text { Method } \\
\text { (mg. } \% \mathrm{Ca})\end{array}$} \\
\hline \multicolumn{2}{|c|}{ Duplicate Estimations } & \multirow[b]{2}{*}{$\begin{array}{c}\text { Mean } \\
8 \cdot 1 \\
7.6 \\
8 \cdot 3 \\
9.1 \\
10.8 \\
12.5 \\
10.8 \\
8.3\end{array}$} & \\
\hline $\begin{array}{r}8 \cdot 1 \\
7.7 \\
8 \cdot 3 \\
9 \cdot 1 \\
10.6 \\
12 \cdot 5 \\
10 \cdot 8 \\
8 \cdot 1\end{array}$ & $\begin{array}{r}8.1 \\
7.4 \\
8.3 \\
9.1 \\
10.9 \\
12.5 \\
10.8 \\
8.4\end{array}$ & & $\begin{array}{r}8.3 \\
7.5 \\
8.3 \\
9.3 \\
11.0 \\
12.6 \\
11.2 \\
8.6\end{array}$ \\
\hline
\end{tabular}

\section{Detailed Technique of Serum Calcium Estimation}

Solutions Required.-The following solutions are required :

Ammonium Oxalate Solution.--This is a saturated solution diluted 1 in 5 with glass-distilled water.

Sulphuric Acid $0.5 \mathrm{~N}$.-Concentrated $\mathrm{H}_{2} \mathrm{SO}_{4}, 14 \mathrm{ml}$., is made up to 1 litre with glass-distilled water.
Propyl Alcohol 10\% v/v.

Stock Calcium Oxalate Standard.-Dried $\mathrm{CaCO}_{3} \mathrm{AR}$, $250 \mathrm{mg}$., is dissolved in $150 \mathrm{ml}$. $0.5 \mathrm{~N} \mathrm{H}_{2} \mathrm{SO}_{4}$. The solution is boiled to remove carbon dioxide, cooled and transferred to a $500 \mathrm{ml}$. volumetric flask, washing in with a further $200 \mathrm{ml}$. $0.5 \mathrm{~N} \mathrm{H}_{2} \mathrm{SO}_{4}$. Then $315 \mathrm{mg}$. oxalic acid A.R., dissolved in a minimum quantity of glass-distilled water, is added followed by $150 \mathrm{ml}$. $0.5 \mathrm{~N} \mathrm{H}_{2} \mathrm{SO}_{4}$.

The solution is then made to $500 \mathrm{ml}$. with glassdistilled water $(1 \mathrm{ml} .=0.2 \mathrm{mg}$. $\mathrm{Ca})$.

Working Standard Calcium Solutions.-The above solution is diluted 5 in 100,10 in 100 , and 15 in 100 with $0.5 \mathrm{~N} \mathrm{H}_{2} \mathrm{SO}_{4}$ (1 $\mathrm{ml}$. of these solutions corresponds respectively to $5 \mathrm{mg}$., $10 \mathrm{mg}$., and $15 \mathrm{mg}$. $\% \mathrm{Ca}$ when $0.2 \mathrm{ml}$. serum is used).

Method.-Glass-stoppered centrifuge tubes are used to facilitate mixing of the final solution and to avoid any contamination. Grade $A$ pipettes are used throughout. To the centrifuge tube are added serum $(0.2 \mathrm{ml}$.) and ammonium oxalate solution $(0.4 \mathrm{ml}$.). The solutions are mixed by gentle "flicking" and allowed to stand for 30 minutes. At the end of this time the tube is centrifuged for 10 minutes at 2,500 r.p.m., the supernatant liquid carefully decanted, and the tube allowed to drain for 10 minutes on a filterpaper. The end and inside of the tube are then wiped with a rolled-up piece of clean filter-paper, $0.5 \mathrm{~N}$ $\mathrm{H}_{2} \mathrm{SO}_{4}(1 \mathrm{ml}$.) added, and the calcium oxalate precipitate dissolved by placing the tube in a boiling water bath for two minutes. After cooling $10 \%$ propyl alcohol $(2 \mathrm{ml}$.) is added and the solutions well mixed by inversion several times. Standard calcium solutions $(1 \mathrm{ml}$.) are diluted with $10 \%$ propyl alcohol ( $2 \mathrm{ml}$.) in glass-stoppered tubes and well mixed. The solutions are now ready for spraying, which is done in smaller beakers than those supplied with the instrument. Pyrex micro beakers (capacity $5 \mathrm{ml}$.) are satisfactory.

Instrument Setting.-With the calcium filter (supplied by the makers of the flame photometer) in place and the potentiometer dial turned fully clockwise to position 1 , the gas is turned on, lit, and the air pressure adjusted to $15 \mathrm{lb} . / \mathrm{sq}$. in. A blank solution $(1.0 \mathrm{ml}$. $0.5 \mathrm{~N} \mathrm{H}_{2} \mathrm{SO}_{4}+2.0 \mathrm{ml}$. $10 \%$ propyl alcohol) is sprayed and the gas reduced during the spraying until the separate cones appear. For constant readings the cones should not coalesce when the solutions are sprayed. After an initial warming-up period of about five minutes the galvanometer is adjusted to zero with the blank solution and the test or standard solution is sprayed. The galvanometer remains steady at maximum deflection and readings can be estimated to $\frac{1}{4}$ division on the lower scale ( 1 division $=2$ units). In later models of the flame photometer this scale is the only one provided. A standard solution (10 $\mathrm{mg}$. $\mathrm{Ca} \%$ ) is sprayed before the test and another standard solution ( $5 \mathrm{mg}$. or $15 \mathrm{mg}$. Ca\%) after the test. The zero is checked and adjusted if necessary by spraying the blank solution between each reading. If the test 
contains $<10 \mathrm{mg} . \% \mathrm{Ca}$ the $5 \mathrm{mg}$. standard is sprayed, and if $>10 \mathrm{mg}$. $\mathrm{Ca} \%$ the $15 \mathrm{mg}$. standard is used. The concentration of the calcium in the unknown solution is calculated by interpolation as follows:

$$
\frac{T-S_{1}}{x}=\frac{S_{2}-S_{1}}{5} \text { or } \frac{T-S_{2}}{x}=\frac{S_{3}-S_{2}}{5}
$$

where $\mathbf{T}=$ galvanometer reading of test solution

$$
\begin{array}{llll}
S_{1}= & \text {, } & \text { " } & \text { " } 5 \mathrm{mg} \text {. standard } \\
S_{2}= & \text { " } & \text { " } & \text { "10 mg. standard } \\
S_{3}= & \text { " } & \text { " } & \text { "15 mg. standard }
\end{array}
$$

The concentration of calcium in the test will then be $(5+x)$ or $(10+x) \mathrm{mg} . \%$.

\section{Summary}

A method for the micro estimation of serum calcium is described using $0.2 \mathrm{ml}$. serum and the Eel flame photometer. The sensitivity of the instru- ment is increased by working at $15 \mathrm{lb}$./sq. in. air pressure and using 10\% propyl alcohol in the sprayed liquid. Satisfactory recovery of calcium in human serum is shown, and results obtained show good agreement with those using the flame photometric method of Llaurado.

The author is grateful to Dr. A. J. McCall for his helpful criticism of the manuscript. Thanks are due to Mrs. C. E. D. Jackson for technical assistance and also to Mrs. P. Tyson.

\section{REFERENCES}

Clark, E. P., and Collip, J. B. (1925). J. biol. Chem., 63, 461. Kingsley, G. R., and Schaffert, R. R.(1953). Analyt.Chem.,25, 1738. - (1954). J. biol. Chem., 206, 807.

Llaurado, J. G. (1954). J. clin. Path., 7, 110. (1951). Amer. J. clin. Path., 21, 75.

Powell, F. J. N. (1953). Ibid., 6, 286.

Severinghaus, J. W., and Ferrebee, J. W. (1950). J. biol. Chem. 187, 621 . 